\title{
24. PALYNOLOGY OF THE VALANGINIAN-BARREMIAN IN HOLE 638B, BARREMIAN-ALBIAN IN HOLE 641C, AND TURONIAN IN HOLE 641A, OCEAN DRILLING PROGRAM LEG 1031
}

\author{
Warren S. Drugg, Chevron Oil Field Research Company, LaHabra, California \\ and \\ Daniel Habib, Queens College, Flushing, New York
}

\begin{abstract}
The palynology of Holes 638B, 641A, and 641C, drilled along the seaward edge of the Galicia margin during ODP Leg 103, is reported. Palynological study of intervals in Hole 638B indicates that Cores 103-638B-39R through 103638B-33R are of Valanginian age, Cores 103-638B-32R to 103-638B-24R are Hauterivian, and Cores 103-638B-23R to 103-638B-21R are Barremian. In Hole 641C, Core 103-641C-16R to Sample 103-641C-12R-6, 121-123 cm, is Barremian in age, and Sample 103-641C-12R-2, 138-140 cm, to Core 103-641C-8R is Aptian. Dinoflagellate evidence indicates that magnetic Chron M0, identified in Core 103-641C-10R, is of Aptian age. The interval represented by Cores 103$641 \mathrm{C}-6 \mathrm{R}$ to $103-641 \mathrm{C}-1 \mathrm{R}$ is Albian. The Lower Cretaceous sequence of Holes 638B and 641C is characterized by the abundance of terrigenous organic particles of the tracheal facies, and it reflects the oceanward transition from the exinitic facies reported previously from DSDP Site 398, south of Vigo Seamount on the Galicia margin. The marine carbon-rich xenomorphic facies of Core 103-641A-6X is Turonian, possibly close to the Cenomanian/Turonian boundary.
\end{abstract}

\section{INTRODUCTION}

The five drill sites of Leg 103 of the Ocean Drilling Program (ODP) are at the seaward edge of the Galicia margin, across a series of north-trending elongate blocks that experienced episodes of tilting during the Early Cretaceous (Boillot, Winterer, et al., 1987). The purpose of ODP Leg 103 drilling was to study the tectonic events associated with the rifting apart of Newfoundland and Iberia and the subsequent history of seafloor spreading. The palynology of three holes drilled at two of the sites, Hole 638B at Site 638 and Holes 641A and 641C at Site 641 (Fig. 1), was studied with the specific objectives of dating the Lower Cretaceous sequence of Holes 638B and 641C and dating the organic-matter-rich "sapropel" recovered from Hole 641A.

Hole $638 \mathrm{~B}$ was drilled at $42^{\circ} 09.2^{\prime} \mathrm{N}, 12^{\circ} 11.8^{\prime} \mathrm{W}$, in a water depth of $4661 \mathrm{~m}$. The 16 samples studied palynologically are from 15 cores representing a depth range from approximately $190 \mathrm{~m}$ below seafloor (mbsf) in Core 103-638B-21R to $363 \mathrm{mbsf}$ in Core 103-638-39R (Table 1). Four lithologic subunits within this interval (IIA, IIB, IIIA, and IIIB; Fig. 2) are described in the "Site 638" chapter (Shipboard Scientific Party, 1987a). The palynology of the upper subunit (lithologic Subunit IIA) was studied from Samples 103-638B-21R-2, 50-52 cm, to 103-638B$23 \mathrm{R}-1,66-67 \mathrm{~cm}$. This subunit consists of alternating cycles of bioturbated limestone and laminated marl. The next lower subunit (lithologic Subunit IIB) was studied from Samples 103-638$24 \mathrm{R}-3,7-9 \mathrm{~cm}$, to $103-638 \mathrm{~B}-32 \mathrm{R}-1,30-32 \mathrm{~cm}$. It consists of bioturbated marl with in-situ sediment deformation, suggesting that the entire subunit was involved in a downslope movement. The interval from Sample 103-638B-33R-1, 52-54 cm, to the bottommost Sample 103-638B-39R-1, 8-9 cm, represents the upper part of lithologic Unit III (Subunits IIIA and IIIB). In contrast to the predominantly marly sediments of the two stratigraphically higher subunits, Unit III is characterized by terrigenous turbidites comprising more than $90 \%$ of the recovered sediment in many of the cores. The background lithology is lami-

\footnotetext{
${ }^{1}$ Boillot, G., Winterer, E. L., et al., 1988. Proc. ODP, Sci. Results, 103: College Station, TX (Ocean Drilling Program).
}

nated marl, but there is an abundance of silty claystone and sandstone turbidites, especially in Subunit IIIB.

The lithologic units of Hole 638B are separated by tectonic contacts, which imply hiatuses between the units, and by evidence of contemporaneous slumping.

Hole $641 \mathrm{C}$ was drilled at $42^{\circ} 09.3^{\prime} \mathrm{N}, 12^{\circ} 10.9^{\prime} \mathrm{W}$, in a water depth of $4640 \mathrm{~m}$. The 19 samples for palynological study are from 15 cores representing a depth range from $151 \mathrm{mbsf}$ in Core $103-641 \mathrm{C}-1 \mathrm{R}$ to the bottom of the hole, $305 \mathrm{mbsf}$ in Core 103-

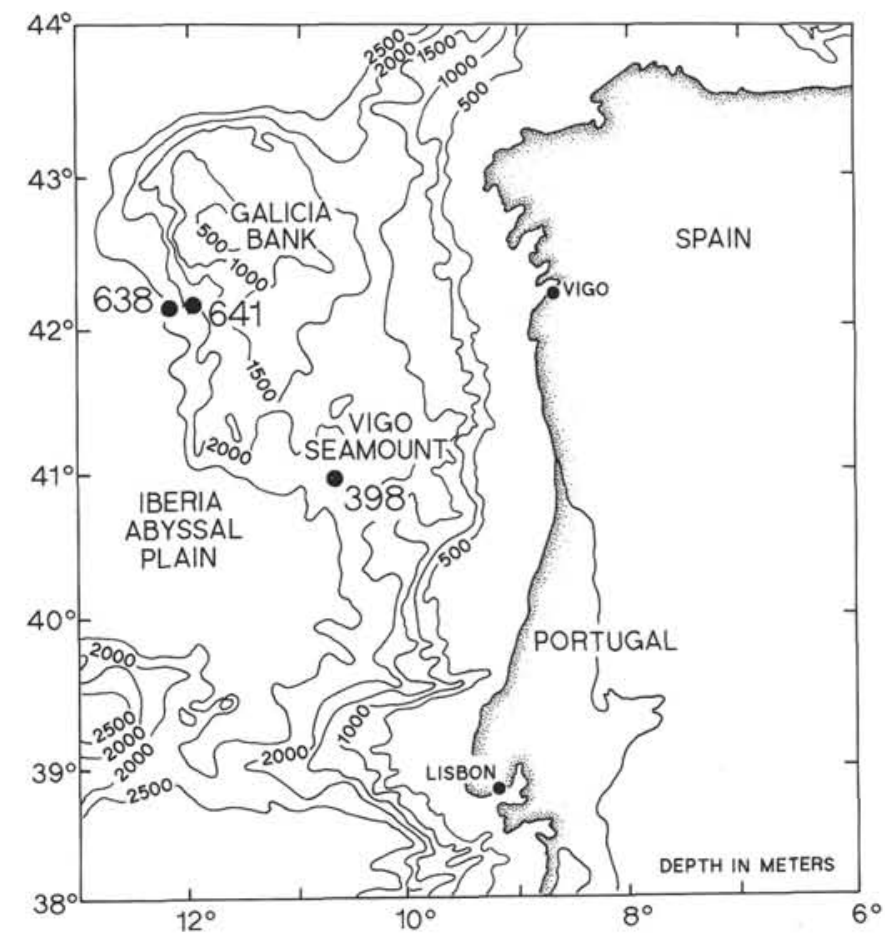

Figure 1. Geographic locations of ODP Sites 638 and 641 and DSDP Site 398. 


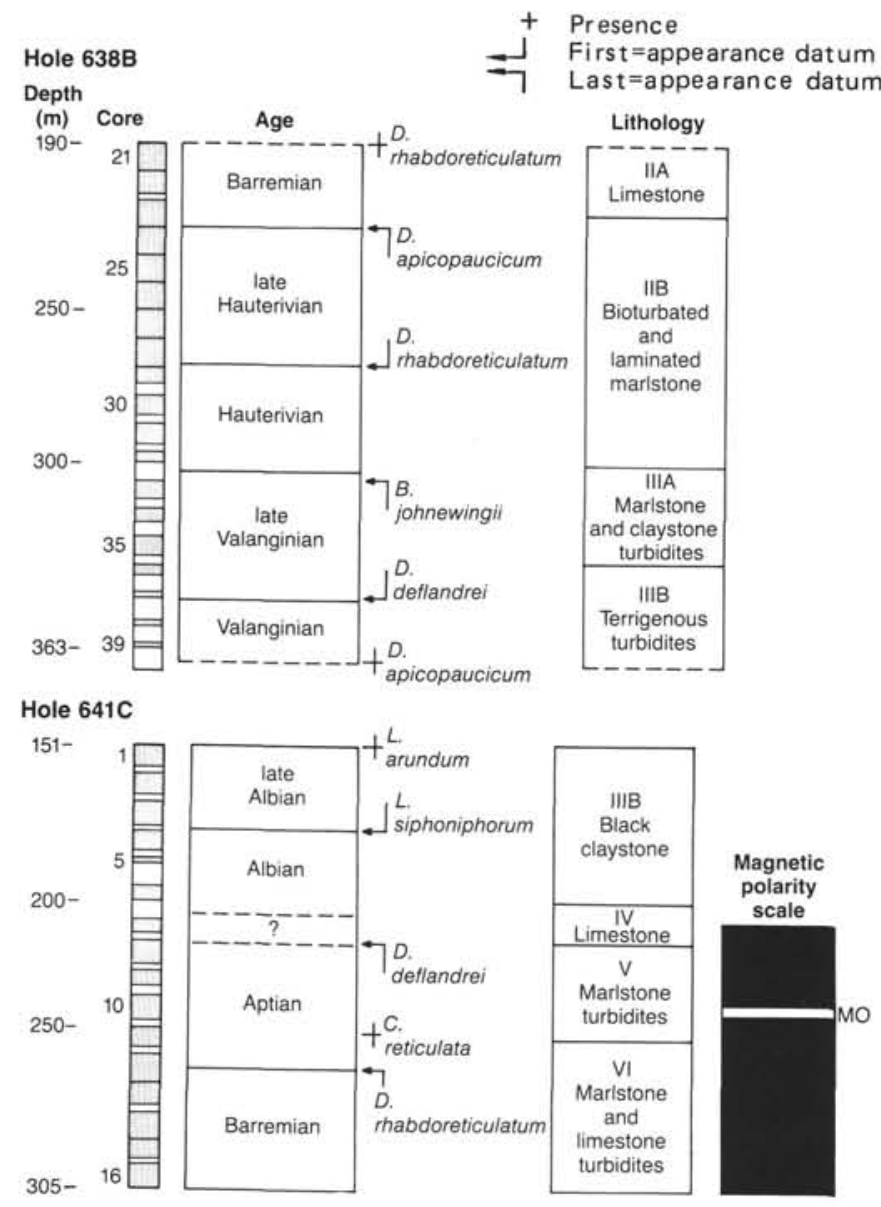

Figure 2. Chronostratigraphically useful dinoflagellate datums plotted against lithologic units in ODP Sites 638 and 641.

641C-16R (Table 1). The shipboard scientific party ("Site 641" chapter; 1987b) distinguished four lithologic units (IIIB, IV, V, and VI) at this site (Fig. 2), each of which is represented by at least one sample in this study. The uppermost lithology recovered in Hole 641C (lithologic Subunit IIIB) consists mainly of greenish black to black claystone. Sedimentary structures vary from laminated to massive to lightly bioturbated. Most commonly, black claystone forms the lamination. The interval palynologically studied is Sample 103-641C-1R-4, 27-30 cm, just below a 208-cm-thick debris flow, to Sample 103-641C-6R-3, $31-32 \mathrm{~cm}$.

Lithologic Unit IV is a relatively thin unit ( $15 \mathrm{~m}$ thick), of which only Sample 103-641C-7R-2, 79-80 cm, was palynologically studied. The lithology of this unit consists of marlstone and limestone turbidites, with thin graded beds, each having a sharp basal contact and a gradational top. Lithologic Unit V includes Samples 103-641C-8R-3, 83-85 cm, to 103-641C-11R-2, $58-60 \mathrm{~cm}$. It consists primarily of greenish gray calcareous microturbidites and marlstone. Blackish claystones alternate with the greenish gray lithologies, but their abundance decreases dramatically in the lower part of Unit V. Bioturbation is characteristically much more abundant in the greenish claystones than in the blackish claystones. Lithologic Unit VI consists chiefly of alternating light gray bioturbated limestone, bioturbated marlstone, and calcareous microturbidites. The palynologically studied interval in Unit VI ranges from Sample 103-641C-11R-4, 80$83 \mathrm{~cm}$, to the stratigraphically lowest sample, 103-641C-16R-7, $143-145 \mathrm{~cm}$.

Hole $641 \mathrm{~A}$ was drilled at $42^{\circ} 09.3^{\prime} \mathrm{N}, 12^{\circ} 10.9^{\prime} \mathrm{W}$, in a water depth of $4636 \mathrm{~m}$. Six samples were collected for study from
Table 1. List of samples studied from Leg 103.

\begin{tabular}{cc}
\hline Site 638 & Site 641 \\
\hline $103-638 \mathrm{~B}-21 \mathrm{R}-2,50-52 \mathrm{~cm}$ & 103-641A-6X-7, 24-25 cm \\
$21 \mathrm{R}-6,52-54 \mathrm{~cm}$ & $6 \mathrm{X}-7,29-30 \mathrm{~cm}$ \\
$22 \mathrm{R}-3,14-16 \mathrm{~cm}$ & $6 \mathrm{X}-7,30-31 \mathrm{~cm}$ \\
$23 \mathrm{R}-1,66-67 \mathrm{~cm}$ & $6 \mathrm{X}, \mathrm{CC}(16-17 \mathrm{~cm})$ \\
$24 \mathrm{R}-3,7-9 \mathrm{~cm}$ & $6 \mathrm{X}, \mathrm{CC}(34-35 \mathrm{~cm})$ \\
$27 \mathrm{R}-6,34-36 \mathrm{~cm}$ & $6 \mathrm{X}, \mathrm{CC}(38-39 \mathrm{~cm})$ \\
$28 \mathrm{R}-3,95-97 \mathrm{~cm}$ & $103-641 \mathrm{C}-1 \mathrm{R}-4,27-30 \mathrm{~cm}$ \\
$29 \mathrm{R}-2,23-25 \mathrm{~cm}$ & $2 \mathrm{R}-6,122-124 \mathrm{~cm}$ \\
$30 \mathrm{R}, \mathrm{CC}(0-2 \mathrm{~cm})$ & $3 \mathrm{R}-4,43-45 \mathrm{~cm}$ \\
$31 \mathrm{R}-1,114-116 \mathrm{~cm}$ & $4 \mathrm{R}-5,47-49 \mathrm{~cm}$ \\
$32 \mathrm{R}-1,30-32 \mathrm{~cm}$ & $6 \mathrm{R}-3,31-32 \mathrm{~cm}$ \\
$33 \mathrm{R}-1,52-54 \mathrm{~cm}$ & $7 \mathrm{R}-2,79-80 \mathrm{~cm}$ \\
$35 \mathrm{R}-7,60-64 \mathrm{~cm}$ & $8 \mathrm{R}-3,83-85 \mathrm{~cm}$ \\
$36 \mathrm{R}-2,130-132 \mathrm{~cm}$ & $9 \mathrm{R}-2,100-102 \mathrm{~cm}$ \\
$37 \mathrm{R}-1,42-45 \mathrm{~cm}$ & $10 \mathrm{R}-3,12-15 \mathrm{~cm}$ \\
$39 \mathrm{R}-1,8-9 \mathrm{~cm}$ & $10 \mathrm{R}-4,6-8 \mathrm{~cm}$ \\
& $10 \mathrm{R}-6,1-3 \mathrm{~cm}$ \\
& $11 \mathrm{R}-2,58-60 \mathrm{~cm}$ \\
& $11 \mathrm{R}-4,80-83 \mathrm{~cm}$ \\
& $12 \mathrm{R}-2,138-140 \mathrm{~cm}$ \\
& $12 \mathrm{R}-6,121-123 \mathrm{~cm}$ \\
& $13 \mathrm{R}-5,31-33 \mathrm{~cm}$ \\
& $14 \mathrm{R}-5,112-115 \mathrm{~cm}$ \\
& $15 \mathrm{R}-1,78-80 \mathrm{~cm}$ \\
& $16 \mathrm{R}-7,143-145 \mathrm{~cm}$ \\
&
\end{tabular}

within and close to lithologic Unit II in Core 103-641A-6X. Unit II consists of a uniform, structureless, black zeolitic clay rich in organic matter (Shipboard Scientific Party, 1987b).

\section{PALYNOLOGY}

\section{METHODS OF INVESTIGATION}

Forty-one samples were analyzed for palynological study. Hydrochloric and hydrofluoric acids were used to remove the mineral sediment in order to collect the organic matter as a residue. Partial oxidation with nitric acid was not used. Four microscope slides were prepared for each sample. An aliquot of the residue was mounted on the first slide for determination of the organic facies. The residue was then filtered through a $20-\mu \mathrm{m}$ screen. Two slides were prepared from the fraction larger than $20 \mu \mathrm{m}$; these slides were analyzed for their palynomorph content. The fourth slide was prepared from the fraction smaller than $20 \mu \mathrm{m}$. All of the samples yielded palynomorphs and an admixture of amorphous debris and/or vascular tissue and/or inertinite. Pyrite microcrystals were observed as common within bisaccate pollen grains and dinoflagellate cysts in the Lower Cretaceous of Holes 638B and 641C.

The stratigraphic age determinations are based to a large extent on the stratotype-calibrated dinoflagellate stratigraphy of Neocomian stages (Habib and Drugg, 1983; Kent and Gradstein, 1985) and on the dinoflagellate stratigraphy studied at DSDP Sites 534 (Sheridan, Gradstein, et al., 1983) and 603 (van Hinte, Wise, et al., 1987) in the western North Atlantic (Habib and Drugg, 1983, 1987). In general, the dinoflagellate stratigraphy at Sites 638 and 641 is similar to that in the western North Atlantic. Figure 2 illustrates the dinoflagellate evidence used for dating the investigated intervals of Holes 638B and 641C.

\section{Hole 638B}

In Hole 638B, the interval investigated from the bottom sample, 103-638B-39R-1, 8-9 cm, through Sample 638B-33R-1, 52$54 \mathrm{~cm}$, (Table 1) is of Valanginian age. Evidence for this age is drawn from the presence in Sample 103-638B-39R-1, 8-9 cm, of Druggidium apicopaucicum Habib, which first appears just above the base of the Valanginian in the stratotype stratigraphy and not later in the early Valanginian as indicated by Moullade et al. (this volume). Sample 103-638B-33R-1, 52-54 cm, is considered to be within the Valanginian based on the presence of Biorbifera johnewingii Habib. Druggidium deflandrei (Millioud) Habib first appears in Sample 103-638B-37R-1, 42-45 cm, which indicates that the interval from that sample to the highest occurrence of $B$. johnewingii is within the upper Valanginian. Other species in the Valanginian of Hole 638B include Muderongia 
simplex Alberti, Phoberocysta neocomica (Gocht) Millioud, Pseudoceratium pelliferum Gocht, Prismatocystis cylindrica Habib, Achomosphaera sp., Scriniodinium campanulum Gocht, Wallodinium krutzschii (Alberti) Habib, and Chlamydophorella sp.

The samples in the Hole 638B Valanginian interval contain organic residues that are rich in particles produced by land plants. Relatively well-preserved and structured fragments of vascular tissue are common occurrences in addition to relatively large and/or ornamented species of pteridophyte spores in the genera Converrucosisporites, Pilosisporites, Concavissimisporites, Aequitriradites, Densoisporites, Cicatricosisporites, Appendicisporites, and Costatoperferosporites. There are also isolated occurrences of recycled spores of apparent Carboniferous age. Classopollid and bisaccate pollen grains are the most abundant palynomorphs in the samples.

The interval from Samples 103-638B-32R-1, 30-32 cm, to 103-638-24R-3, 7-9 cm, is Hauterivian. Although there is no evidence of the Valanginian/Hauterivian boundary, samples representing this interval are characterized by the absence of $B$. johnewingii and by the continuing occurrence of $D$. apicopaucicum. $D$. deflandrei is the most commonly occurring dinoflagellate species. Druggidium rhabdoreticulatum Habib first appears in Sample 103-638B-28R-3, 95-97 cm, which indicates that the interval from this sample to Sample 103-638-24R-3, 7-9 cm, is within the late Hauterivian. Dingodinium cerviculum Cookson and Eisenack and Kallosphaeridium sp. become common constituents in the interval characterized by the presence of $D$. rhabdoreticulatum. An increase in the abundance of $D$. cerviculum with the first appearance of $D$. rhabdoreticulatum corresponds to that noted at DSDP Site 105 in the western North Atlantic (Habib, 1976, fig. 3). At DSDP Hole 534A, the first appearance of Kallosphaeridium sp. is of late Hauterivian age (Habib and Drugg, 1983).

Organic residues of Hauterivian age continue to be characterized by the occurrence of pteridophyte spores and relatively well-preserved vascular tissue. However, Sample 103-638B-24R-3, 7-9 cm, contains abundant amorphous debris.

Assemblages recovered from Samples 103-638B-23R-1, 66$67 \mathrm{~cm}, 103-638 \mathrm{~B}-22 \mathrm{R}-3,14-16 \mathrm{~cm}, 103-638 \mathrm{~B}-21 \mathrm{R}-6,52-54 \mathrm{~cm}$, and 103-638B-21R-2, 50-52 cm, contain D. rhabdoreticulatum, D. deflandrei, Kallosphaeridium sp., D. cerviculum, Phoberocysta neocomica, Polysphaeridium warrenii Habib, and $\mathrm{Mu}$ derongia simplex among other species. These samples are considered to be of Barremian age, based on the presence of these species and the apparent absence of $D$. apicopaucicum. In the stratotype-based stratigraphy, D. apicopaucicum does not range consecutively to sediments younger than late Hauterivian. Other species are useful for suggesting an age not younger than Barremian. These include $M$. simplex and $D$. rhabdoreticulatum. The range of $P$. neocomica is known to be younger than earliest Aptian (early Bedoulian). In De Renéville and Raynaud's (1981) dinoflagellate stratigraphy of the stratotype section of the Barremian Stage, the range of $D$. rhabdoreticulatum is not younger than late Barremian. In the western North Atlantic, these species have consecutive ranges to just past the top of the Barremian, although there are single occurrences in isolated samples of the Aptian, such as at DSDP Site 534 (Habib and Drugg, 1983). The organic residues from these samples contain abundant amorphous debris and fecal pellets. Classopollid and bisaccate pollen grains are still the most abundant group of palynomorphs, but the number of dinoflagellate species and small acritarchs also increases. Kallosphaeridium sp. is an abundant constituent among the dinocysts. The larger and more highly ornamented pteridophyte spores are only poorly represented, and most vascular tissue is carbonized.

\section{Hole $641 \mathrm{C}$}

The age of the interval from Samples 103-641C-16R-7, 143$145 \mathrm{~cm}$, through $105-641 \mathrm{C}-12 \mathrm{R}-6,121-123 \mathrm{~cm}$, is Barremian.
This age is evidenced by the occurrence of $D$. rhabdoreticulatum, the abundance of $D$. deflandrei, and in most samples, the absence of $D$. apicopaucicum. One specimen questionably referred to D. apicopaucicum was observed in Sample 103-641C-12R-6, $121-123 \mathrm{~cm}$, but it is considered to be recycled. Other species in the Barremian sequence of Hole $641 \mathrm{C}$ include Kallosphaeridium sp., Chlamydophorella nyei Cookson and Eisenack, Oligosphaeridium asterigerum (Gocht) Davey and Williams/O. complex (White) Davey and Williams, Subtilisphaera perlucida (Alberti) Jain and Millipied, Polysphaeridium warrenii, Scriniodinium campanulum, and Callaiosphaeridium asymmetricum.

The interval from Samples 103-641C-12R-2, 138-140 cm, through $103-641 \mathrm{C}-8 \mathrm{R}-3,83-85 \mathrm{~cm}$, is of Aptian age. This age assignment is based on the presence of $D$. deflandrei and absence of D. rhabdoreticulatum. Sample 103-641C-11R-2, 58$60 \mathrm{~cm}$, contains Cassiculosphaeridia reticulata Davey, which, in the absence of $D$. rhabdoreticulatum, strongly supports an Aptian age assignment. At both Sites 534 and $603, C$. reticulata first appears close to the Barremian/Aptian boundary in the presence of $D$. rhabdoreticulatum. Dinoflagellate species are relatively few in the Aptian, which is similar to the situation in DSDP sites in the western North Atlantic.

The assemblage in Sample 103-641C-7R-2, 79-80 cm, consists mainly of inertinite. Palynomorphs are rare and are not age diagnostic.

The interval represented by Samples 103-641C-6R-3, 31-32 cm, through 103-641C-1R-4, 27-30 cm, is Albian in age. Assemblages of late Albian age occur in Samples 103-641C-3R-4, 43$45 \mathrm{~cm}, 103-641 \mathrm{C}-2 \mathrm{R}-6,122-124 \mathrm{~cm}$, and 103-641C-1R-4, 27-30 $\mathrm{cm}$, based of the occurrence of Litosphaeridium siphoniphorum (Cookson and Eisenack) Davey and Williams, Systematophora cretacea Davey, and Codoniella psygma Davey. Sample 103$641 \mathrm{C}-1 \mathrm{R}-4,27-30 \mathrm{~cm}$, is not younger than late Albian because of the presence of Litosphaeridium arundum (Eisenack and Cookson) Davey.

\section{Hole 641A}

Most samples studied from this blackish, organic-carbonrich clay interval of Core 103-641A-6X contain residues rich in well-preserved amorphous debris of the xenomorphic facies. The samples contain classopollid and bisaccate pollen grains and few pteridophyte spores. The Normapolles pollen genera Atlantopollis and Complexiopollis, each represented by several species, are common in the samples and indicate a Late Cretaceous age within the Cenomanian-Turonian. Samples 103-641A-6X-7, 24-25 cm, 103-641A-6X, CC (16-17 cm), 103-641A-6X, CC $(34-35 \mathrm{~cm})$, and 103-641A-6X, CC (38-39 cm), contain smaller organic residues but a more varied dinoflagellate flora, including Spiniferites cingulatus, Palaeohystrichophora infusorioides Deflandre, Codoniella psygma, and Odontochitina operculata (Wetzel) Deflandre and Cookson. Sample 103-641A-6X, CC (34-35 cm), also contains Chatangiella sp. and Protoellipsodinium sp. sensu Foucher (in Robaszynski et al., 1982, pl. 11, figs. 1 and 2). This sample also contains the Normapolles pollen species identified as Atlantopollis sp. 3 by Legoux (in Robaszynski et al., 1982). The genus Chatangiella does not occur in sediments older than early Turonian. In the type region of the Turonian studied by Robaszynski et al. (1982), Foucher's species Protoellipsodinium sp. is restricted to the Cenomanian, but adjacent to the Cenomanian/Turonian boundary. The pollen Atlantopollis sp. 3 is restricted to the Turonian in the type region. Based on this evidence and the diversification of Normapolles pollen types, Sample 103-641-6X, CC (34-35 cm), is considered to be of Turonian age and possibly close to the Cenomanian/Turonian boundary.

\section{CONCLUSIONS}

In Hole 638B, several of the chronostratigraphically useful dinoflagellate species datums coincide with the boundaries of 
the major lithologic units. This implies that the contacts of the major lithologies are not stratigraphically conformable. In Hole $641 \mathrm{C}$, the dinoflagellate stratigraphy indicates a more conformable transition between the lithologies.

The Valanginian was identified in Hole 638B in the upper part of lithologic Unit III, of which the upper two-thirds is of late Valanginian age (Fig. 2). The organic facies is characterized by an abundant supply of terrigenous organic detritus, with an admixture of well-preserved dinoflagellate cysts of the tracheal facies (Habib, 1982). This facies directly correlates to the abundance of terrigenous turbidites in Unit III.

Lithologic Subunit IIB of Hole 638B is of Hauterivian age. The upper half of the unit is of late Hauterivian age. The organic facies is tracheal throughout the Hauterivian, but is less well developed than in the Valanginian.

Lithologic Subunit IIA in Hole 638B and much of Unit VI in Hole $641 \mathrm{C}$ are of Barremian age, consisting of alternating lithologies of bioturbated limestone and laminated marl. Dinoflagellates are more common in the interval and are usually very well preserved and diversified. In Hole $638 \mathrm{~B}$, the organic residues consist mostly of well-preserved amorphous debris that, together with the increased number of dinoflagellate species, distinguishes the xenomorphic facies. In Hole 641C, the Barremian/Aptian boundary is considered to lie within the upper part of this limestone unit, within Core 103-641C-12R, based on the last consecutive stratigraphic occurrence of Druggidium rhabdoreticulatum.

The Aptian is identified from within the uppermost part of lithologic Units VI through V in Hole 641C. The Barremian/ Aptian boundary occurs within the uppermost part of the limestone unit, which is similar to its occurrence in the Blake-Bahama Formation in the western North Atlantic (e.g., Habib and Drugg, 1983, 1987). It is succeeded stratigraphically by an Aptian lithologic unit that is transitional to an overlying lithology characterized by calcium carbonate-poor black clay. This occurrence is also similar to the situation in the western North Atlantic within the Hatteras Formation.

The age of lithologic Unit IV at Hole $641 \mathrm{C}$ has not been determined owing to poor recovery of palynomorphs. All of lithologic Subunit IIIB at Hole $641 \mathrm{C}$ is of Albian age.

The organic-matter-rich black clay of Core 103-641A-6X is of Turonian age, possibly close to the Cenomanian/Turonian boundary. The organic facies is typically xenomorphic and is characterized by (1) an abundance of well-preserved amorphous debris considered to be largely of zooplanktonic fecal origin; (2) an increased number of dinoflagellate species, which is not necessarily accompanied by a proportionally increased number of specimens; and (3) in the Cenomanian-Turonian interval, by the common occurrence of well-preserved and diversified "windblown" angiospermous pollen of the Normapolles group (e.g., Atlantopollis, Complexiopollis). This facies occurs at a number of sites in the Cenomanian-Turonian of the North Atlantic, such as DSDP Sites 105, 398, 534, and 603 (Habib and Drugg, 1987). It is organic carbon rich and primarily of marine origin, according to kerogen analysis.

The abundance of terrigenous organic particles in the Lower Cretaceous sequence at Sites 638 and 641 compares favorably with the similar occurrence of terrigenous organic facies in the Lower Cretaceous of Site 398, approximately $90 \mathrm{~km}$ to the southeast (Fig. 1). However, these assemblages at Site 398 are dominated by pteridophyte spores and classopollid and bisaccate pollen grains to the virtual exclusion of dinoflagellate cysts in the exinitic organic facies (Habib, 1979). At Sites 638 and 641 there is an admixture of dinoflagellate cysts and pteridophyte spores in the tracheal facies. This oceanward transition from the exinitic facies to the tracheal facies in terrigenous sediments is in good accordance with the oceanward transition model of terrigenous organic matter sedimentation proposed by Habib (1982).

The presence of pyrite microcrystals within bisaccate grains and within dinoflagellate cysts in the Lower Cretaceous sequence of Sites 638 and 641 suggests that they are a result of anaerobic microbial digestion of existing cytoplasm at the sediment/water interface or within the buried sediment environment (E. I. Robbins, pers. comm., 1987). If this supposition is accurate, it implies that these palynomorphs were delivered to the seafloor with their cytoplasm intact.

Ogg (this volume) has studied the paleomagnetic stratigraphy of the Cretaceous sequence recovered by ODP Leg 103 and has identified the well-defined M0 Chron in Core 103-641C-10R. According to the dinoflagellate stratigraphy of Hole 641C, Chron M0 is of Aptian age.

\section{ACKNOWLEDGMENTS}

We are grateful to E. I. Robbins, J. Ogg, L. E. Edwards, and G. L. Williams, who criticized the manuscript for us. Chevron Oil Field Research Company kindly provided time and facilities for this study. The Ocean Drilling Program kindly provided the samples. The samples were prepared for study by J. Sanocki. L. McClain typed the manuscript. This study was supported by a grant from the National Science Foundation, OCE-8303695.

\section{REFERENCES}

Boillot, G., Winterer, E. L., et al., 1987. Proc. ODP, Init. Repts., 103: College Station, TX (Ocean Drilling Program).

De Renéville, P., and Raynaud, J.-F., 1981. Palynologie du stratotype du Barrémien. Bull. Cent. Rech. Explor. Prod. Elf Aquitaine, 5:129.

Habib, D., 1976. Neocomian dinoflagellate zonation in the western North Atlantic. Micropaleontology, 21:373-392.

1979. Sedimentology of palynomorphs and palynodebris in Cretaceous carbonaceous facies south of Vigo Seamount. In Sibuet, J.-C., Ryan, W.B.F., et al., Init. Repts. DSDP, 47, Pt. 2: Washington (U.S. Govt. Printing Office), 451-467.

1982. Sedimentation of black clay organic facies in a Mesozoic oxic North Atlantic. Proc. 3rd Nor. Am. Paleontol. Conv., 1: 217-220.

Habib, D., and Drugg, W. S., 1983. Dinoflagellate age of Middle Jurassic-Early Cretaceous sediments in the Blake-Bahama Basin. In Sheridan, R. E., Gradstein, F. M., et al., Init. Repts. DSDP, 76: Washington (U.S. Govt. Printing Office), 623-638.

1987. Palynology of Sites 603 and 605, Leg 93, Deep Sea Drilling Project. In van Hinte, J. E., Wise, S. W., et. al., Init. Repts. DSDP, 93: Washington (U.S. Govt. Printing Office), 751-775.

Kent, D. V., and Gradstein, F. M., 1985. A Cretaceous and Jurassic geochronology. Geol. Soc. Am. Bull., 96:1419-1427.

Robaszynski, F., Alcaydé, G., Amédro, F., Badillet, G., Damotte, R., Foucher, J.-C., Jardiné, S., Legoux, O., Manivit, H., Monciardini, C., and Sornay, J., 1982. Le Turonien de la région-type: Samurois et Touraine. In Stratigraphie, Biozonation, Sedimentologie: Bull. Cent. Rech. Explor. Prod. Elf Aquitaine, 6:119-225.

Sheridan, R. E., Gradstein, F. M., et al., 1983. Init. Repts. DSDP, 76: Washington (U.S. Govt. Printing Office).

Shipboard Scientific Party, 1987a. Site 638. In Boillot, G., Winterer, E. L., et al., Proc. ODP, Init. Repts., 103: College Station, TX (Ocean Drilling Program), 221-407.

1987b. Site 641. In Boillot, G., Winterer, E. L., et al., Proc. ODP, Init. Repts., 103: College Station, TX (Ocean Drilling Program), 571-649.

van Hinte, J. E., Wise, S. W., et al., 1987. Init. Repts. DSDP, 93: Washington (U.S. Govt. Printing Office).

Date of initial receipt: 25 May 1987

Date of acceptance: 15 December 1987

Ms 103B-152 